\title{
PENGARUH USER-GENERATED CONTENT SEBAGAI ALAT KOMUNIKASI BISNIS TERHADAP KREDIBILITAS INFORMASI WEBSITE "TOKOPEDIA"
}

\author{
Muhammad Fariz Pinuji ${ }^{1}$, Satiri Satiri ${ }^{2}$ \\ ${ }^{1}$ Sekolah Tinggi Ilmu Komunikasi Inter Studi \\ Jl Wijaya II No 62 Jakarta 12160 \\ Fariz_pinuji@yahoo.com \\ ${ }^{2}$ International University Liaison Indonesia \\ Jl Masjid No 75 Banten 15330 \\ satiri@iuli.ac.id
}

\begin{abstract}
ABSTRAK
Penelitian ini bertujuan untuk mengetahui Pengaruh User-Generated Content Sebagai Alat Komunikasi Bisnis Terhadap Kredibilitas Informasi Website=Tokopedia'. Hal ini mengingat, faktor pembuatan konten oleh pengguna lain dapat mempengaruhi konsumen didalam melakukan keputusan pembelian. Oleh karena itu, konten atau ulasan produk yang objektif, akurat, dan relevan dengan produk yang diposting yang dibuat pengguna lain maka informasi tersebut akan terlihat kredibel oleh pihak lain. Teori yang digunakan untuk variabel bebas adalah teori E-WOM, dan user-generated content diukur dengan empat dimensi timbal - balik, cepat tanggap, informasi non verbal, dan kecepatan respons. Sedangkan, teori untuk variabel terikat menggunakan model mengadopsi informasi, kredibilitas informasi diukur dengan dua dimensi yakni kualitas argumen dan kredibilitas sumber. Paradigma penelitian positivistik dengan pendekatan kuantitatif. Metode penelitiannya survei. Data penelitian kuesioner disebarkan ke 96 orang dengan teknik sampling secara purposive sampling. Pengujian hipotesis menggunakan rumus regresi linear sederhana. Hasil temuan penelitian menunjukkan bahwa user - generated content sebagai alat komunikasi bisnis berpengaruh signifikan terhadap kredibilitas informasi website Tokopedia. Artinya bahwa konten atau komentar yang dibuat pengguna lain di website Tokopedia ini terlihat kredibel sehingga konsumen lain yang membacanya percaya dengan informasi yang tertera di kolom komentar. Besar Pengaruh User - Generated Content sebagai Alat Komunikasi Bisnis Terhadap Kredibilitas Informasi Website Tokopedia, diperoleh sebesar 0,624 termasuk kategori Hubungan kuat. Artinya bahwa konten atau ulasan produk yang dibuat pengguna lain di Website Tokopedia terlihat informasinya kredibel. Kesimpulan penelitian menunjukkan usergenerated content sebagai alat komunikasi bisnis berpengaruh signifikan terhadap kredibilitas informasi website Tokopedia, dan kategori pengaruhnya termasuk kategori pengaruh kuat.
\end{abstract}

Kata Kunci: Komunikasi Bisnis, Kredibilitas Informasi, Tokopedia, User-Generated Content, Website 


\begin{abstract}
This study aims to determine the effect of User-Generated Content as a Business Communication Tool on the Credibility of 'Tokopedia' Website Information. This is considering, the factor of content creation by other users can influence consumers in making purchasing decisions. Therefore, product content or reviews that are objective, accurate, and relevant to the product posted by other users will make the information look credible to other parties. The theory used for independent variables is the E-WOM theory, and user-generated content is measured by four dimensions of reciprocity, responsiveness, non-verbal information, and response speed. Whereas, the theory for the dependent variable uses the model of adopting information, information credibility is measured by two dimensions namely the quality of the argument and the credibility of the source. The research findings show that user - generated content as a business communication tool has a significant effect on the credibility of the Tokopedia website information. This means that the content or comments made by other users on the Tokopedia website look credible so that other consumers who read them trust the information contained in the comments column. Great Influence of User Generated Content as a Business Communication Tool Against the Credibility of Tokopedia Website Information, obtained by 0.624 including the category of strong influence. This means that the content or product reviews made by other users on the Tokopedia Website look credible information. The conclusion of the study shows that user - generated content as a business communication tool has a significant effect on the credibility of the Tokopedia website information, and the category of influence is included category strong.
\end{abstract}

Keywords: Business Communication, Information Credbility, Tokopedia, Usr-Generated Content, Website

\section{PENDAHULUAN}

Lanskap media telah mengalami transformasi besar selama dekade terakhir (Mangold dan Faulds, 2009) dalam (Bruhn, Coulter, Schoenmueller dan Schäfer, 2012). Media sosial, seperti jejaring sosial atau microblog, semakin menggantikan media tradisional, dan desas-desus tentang peluang pemasaran baru ini tampaknya tidak terbatas. Ditambahkan lagi, anggaran komunikasi disesuaikan kembali ketika pengiklan menjauh dari media tradisional dan menginvestasikan sumber daya yang lebih besar ke dalam iklan digital dan media sosial. Diperkirakan bahwa lebih dari 15 juta merek secara global terdaftar di situs media sosial, dan berusaha menjangkau lebih dari 1 miliar konsumen (Stieglitz et al., 2014) dalam (Dolan, Conduit, Fahy dan Goodman, 2017). Media sosial telah digunakan pebisnis untuk mengkomunikasikan bisnisnya. Komunikasi bisnis dilakukan kepada pelanggan, mitra, dan pemangku kepentingan, telah berkembang secara radikal dalam hal saluran dan sistem, ketika aplikasi virtual dan digital telah memasuki bidang ini, seperti halnya ebisnis yang menantang brick-\&-mortar markets (Brouthers et al ., 2016) dalam (Costa e Silva dan Elo, 2018).

Baru-baru ini, komunikasi sangat dipengaruhi oleh internet dan teknologi. Platform jejaring sosial memengaruhi proses interaksi di antara pengguna internet melalui saluran partisipasi dua arah daripada informasi yang bersifat searah. Media sosial, dengan percepatan perkembangan serupa dalam teknologi seluler, sekarang dapat diakses di mana saja, kapan 
saja (Anzmac, 2010) dalam (Khajuria dan Rachna, 2017). Konsumen tidak diragukan lagi sebagian besar, telah mengadopsi internet.

Adanya akses ke internet dan partisipasi dalam perdagangan online jelas merupakan kunci menuju ekosistem yang kuat. Lebih dari 60 persen UMKM Indonesia berlangsung secara online, tetapi hanya sekitar 15 persen memiliki sistem pemesanan dan pembayaran online (Das, Tamhane, Vatterott, Wibowo, dan Wintels, Agustus 2018). Jual beli online terus mengalami peningkatan di Indonesia, sampai pada akhir 2018, pertumbuhan e-commerce di tanah air semakin positif. E-commerce Indonesia telah menjadi pasar yang persaingannya sangat ketat selama bertahun-tahun karena banyak bisnis yang tertarik dengan potensinya yang sangat besar. Menyadari populasi besar negara Indonesia dan mengantisipasi ledakan digitalnya, perusahaan dan investor lokal dan asing telah meluncurkan website e-commerce, aplikasi, dan pasar. Beberapa dari mereka menjadi sangat sukses, dengan jutaan pengunjung setiap bulan.

Gambar 1. Top 10 e-commerce sites in Indonesian in 2018, by monthly traffic (in million clicks) Sumber : ASEAN UP. (May 2, 2018). Top 10 ecommerce sites in Indonesia in 2018, by monthly traffic (in million clicks). In Statista. Retrieved August 22, 2019, from https://www-statista-com. (ASEAN, 2018)

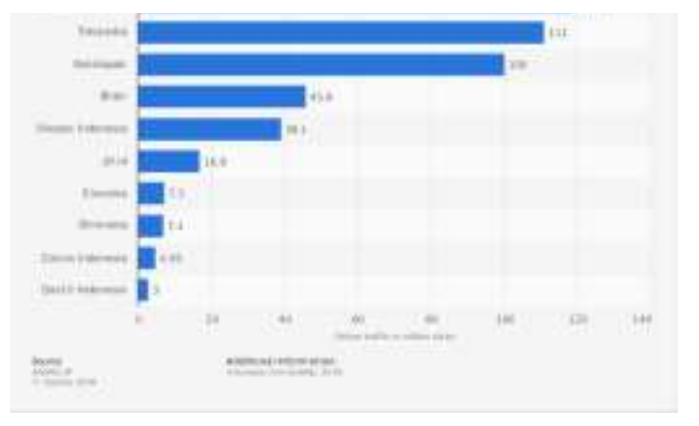

Mengacu gambar 1.1, Statistik ini menggambarkan sepuluh website e-commerce teratas di Indonesia pada tahun 2018, yang dikelompokkan berdasarkan traffic bulanan. Pada tahun 2018, pemimpin pasar Lazada Indonesia memiliki sekitar 118,5 juta kunjungan traffic online, kemudian dilanjutkan website Tokopedia memiliki kunjungan traffic online sebesar 111 (ASEAN, 2018).

Dalam lingkungan e-commerce virtual, website adalah pertama dan alat penghubung utama bagi interaksi dengan konsumen potensial. Website telah menjadi satu-satunya sarana untuk menyampaikan informasi, berkomunikasi dengan calon konsumen dan meningkatkan kesadaran produk (Ness, 2006) dalam (Cho, Bonn dan Kang, 2014: 111). Sistem website yang interface dengan konsumen dapat memainkan peran penting dalam mengurangi risiko yang dirasakan dengan belanja online, banyak perusahaan-perusahaan AS secara online telah membuat upaya untuk mengembangkan website yang efektif yang dapat membangun hubungan yang positif dengan konsumen serta lebih meningkatkan pendapatan penjualan secara online (Nowak dan Newton, 2008) dalam (Cho, Bonn dan Kang, 2014: 111).

Gambar 2. Jumlah Pembeli online di Indonesia pada pada tahun 2017 dan 2022 (dalam jutaan) Sumber : McKinsey. (August 15, 2018). Number of online shoppers in Indonesia in 2017 and 2022

(in millions). In Statista. Retrieved August 22, 2019, from https://www-statista-com. (McKinsey, 2018)

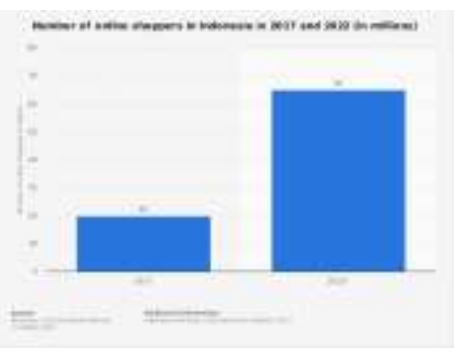


Berdasarkan gambar 1.2 Statistik ini menunjukkan jumlah pembeli online di Indonesia pada tahun 2017 dan 2022. Pada tahun 2017, sekitar 20 juta orang berbelanja online, jumlah ini diperkirakan akan meningkat menjadi 65 juta pada tahun 2022(McKinsey, 2018).

Begitu besarnya pengguna internet memberikan perubahan arah bisnis yang lebih modern dan digital. Hal inilah yang dilakukan pebinis berskala mikro maupun makro yang kini mulai beralih memasarkan bisnisnya di media digital yang terhubung internet. Pebisnis memanfaatkan media website komersial maupun media sosial untuk menjalankan bisnisnya agar produknya diminatibanyak konsumen sehingga berpengaruh pada peningkatan penjualan. Seperti hasil riset yang dilakukan oleh Statista, dengan melakukan survey sebanyak 22.618 konsumen di 2016 menyatakan bahwa sebanyak $45 \%$ pengguna media sosial melihat produk yang dimunculkan pada media sosial atau memberikan komentar, sebanyak 44\% konsumen menerima penawaran promosi produk, sebanyak $22 \%$ konsumen memberikan komentar, dan ternyata sebesar 78\% konsumen dipengaruhi oleh media sosial sehingga pada gilirannya konsumen melakukan belanja online, yang dapat dilihat pada gambar 1.2 di bawah ini.

Gambar 3. Bagaimana Media Sosial Mempengaruhi Perilaku Belanja (The

\section{Great Influencer)}

Sumber: (Richter, 2016)

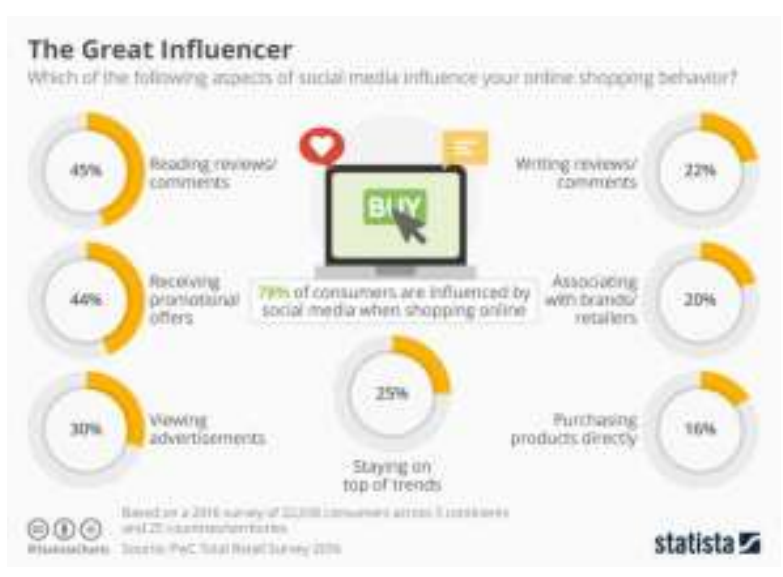

Berdasarkan data riset milik Statista, pada gambar 1.3 memperlihatkan bahwa $78 \%$ konsumen dipengaruhi media sosial sehingga konsumen memutuskan belanja online. Fenomena belanja online akan terus mengalami peningkatan dikarenakan masyarakat sekarang ingin menghemat waktu dan biaya pengeluaran perjalanan. Oleh sebab itu, pebisnis yang berskala mikro maupun makro memanfaatkan media website untuk menjalankan bisnisnya agar dapat menjangkau target sasaran yang lebih luas lagi dan mengalami peningkatan penjualan. Business-toconsumer electronic commerce (B2C e-commerce) merupakan salah satu dari banyak model e-commerce, B2C e-commerce adalah cara yang efektif di mana perusahaan dan pelanggan melakukan transaksi pembelian secara online berbasis teknologi yang telah terhubung dengan internet (Lin, 2007). Bukti kuat menunjukkan bahwa internet telah menjadi alat yang efektif untuk tujuan komersial (Huizingh, 2000) dalam (Mei Cao dan Seydel, 2005). Kehadiran internet dan Web 2.0 mengakibatkan konsumen menjadi lebih proaktif untuk mendapatkan informasi dan melakukan tindakan pembelian (Schivinski dan Dabrowski, 2016). Business-to-Business Electronic Commerce (B2B EC) didefinisikan sebagai teknologi yang terhubung dengan internet yang memungkinkan perusahaan dapat melakukan penjualan produk 
InterScript: Journal of Creative Communication Volume 1, No 1 November 2019

maupun pembelian produk serta layanan yang diberikan secara elektronik, dan konsumen dapat melakukan berbagi informasi yang bermanfaat kepada orang lain (Mohtaramzadeh, Ramayah dan Jun-Hwa, 2017).

Pavlou (2001) dalam (Mei Cao dan Seydel, 2005) berpendapat bahwa ekonomi digital mendorong penciptaan ketentuan kelembagaan untuk mendukung dan menjamin transaksi antara entitas yang tidak memiliki konteks tatap muka yang biasa terjadi pada sistem belanja tradisional. Ada banyak jaminan struktural dan membangun kepercayaan yang disediakan oleh vendor, seperti sertifikasi, jaminan, perjanjian, dan kebijakan. Kepercayaan seperti itu memberikan kondisi impersonal yang menguntungkan dan kondusif untuk kesuksesan transaksional (Mei Cao dan Seydel, 2005). Gefen et al. (2003) dalam (Mei Cao dan Seydel, 2005) berpendapat bahwa kepercayaan adalah aspek penting dari e-commerce karena tidak adanya jaminan yang terbukti bahwa evendor tidak akan terlibat dalam perilaku oportunistik seperti harga yang tidak adil, menyampaikan informasi yang tidak akurat, pelanggaran privasi dan penggunaan kartu kredit tanpa izin informasi.

Dalam konteks e-commerce, dimensi keandalan dari SERVQUAL dapat dijelaskan / diganti dengan konsep kepercayaan. Kepercayaan didefinisikan sebagai penilaian subyektif dari pelanggan percaya bahwa infrastruktur teknologi yang mendasari organisasi dan mekanisme kontrol mampu mendukung transaksi (Mei Cao dan Seydel, 2005). Kepercayaan sangat penting dalam transaksional, hubungan pembeli-penjual dari pelanggan dan $e$ vendor karena risiko dan ketidakpastian lingkungan online. Kepercayaan adalah harapan bahwa e-vendor tidak akan berperilaku oportunis dengan mengambil keuntungan dari situasi (Mei Cao dan Seydel, 2005). Keyakinan pelanggan bahwa e-vendor akan berperilaku dengan cara yang dapat diandalkan, etis, dan sesuai secara sosial.

Online retailers dapat meningkatkan kepuasan dan loyalitas pelanggan dengan memberikan banyak keuntungan seperti kenyamanan, antarmuka pengguna yang dirancang dengan baik, informasi yang disesuaikan, berbagai informasi produk, dan harga kompetitif (Lin, 2007).

Namun, berbisnis online saja tidak menjamin keunggulan kompetitif. Perusahaan e-commerce bergantung pada orang yang mengunjungi website mereka, membeli produk mereka, dan, yang lebih penting, menjadi pelanggan tetap (Smith dan Merchant, 2001) dalam (Mei Cao dan Seydel, 2005). Pada saat yang sama, pelanggan memiliki banyak website yang dapat mereka gunakan sebagai alternatif. Pelanggan tidak akan beralih ke website lain jika memang kinerjanya memuaskan (Bhatti et al., 2000) dalam (Mei Cao dan Seydel, 2005). Perlu diketahui bahwa kompetitor utama dari website Tokopedia di Indonesia, yakni Lazada, Bukalapak, Shopee, Blibli dimana telah berkolaborasi dengan salah satu perusahaan FMCG terbesar di Indonesia, yakni Unilever, dan Zalora.

\section{KERANGKA PEMIKIRAN}

\section{Komunikasi Bisnis}

Komunikasi bisnis adalah komunikasi yang digunakan dalam dunia bisnis yang mencakup berbagai macam bentuk komunikasi, baik komunikasi verbal maupun komunikasi nonverbal untuk mencapai tujuan tertentu (Purwanto, 2006). Dalam dunia bisnis, 
seorang komunikator yang baik di samping harus memiliki kemampuan berkomunikasi yang baik (tentu saja), juga harus mampu menggunakan berbagai macam alat atau media komunikasi yang ada untuk menyampaikan pesan-pesan bisnis kepada pihak lain secara efektif dan efisien, sehingga tujuan penyampaian pesan-pesan bisnis dapat tercapai.

Fill (199) dalam (Varey, 2002) memberikan uraian yang menarik dan komperhensif tentang peran dan sifat komunikasi bisnis, yaitu (1) Membedakan (differentiating): mencoba mengeluarkan produk pesaing dari pengambilan keputusan konsumen dengan membuat produk Anda lebih menarik dan lebih dekat dengan kebutuhan mereka, (2) Mengingatkan (reminding): mencoba memastikan bahwa ketika opsi untuk konsumsi dinilai, produk Anda disertakan, (3) Menginformasikan (informing): menyediakan data ke dalam proses pemikiran konsumen yang penuh pertimbangan dan apresiatif untuk memastikan bahwa produk Anda dianggap sebagai pilihan yang menarik dalam konsumsi, (4) Membujuk (persuading): usaha untuk mendorong perilaku menguntungkan yang diinginkan dari konsumen.

\section{E-Commerce}

E-Commerce merujuk pada penggunaan Internet dan Web untuk melakukan transaksi bisnis (Laudon dan Laudon, 2008). Secara spesifik, $e$ commerce adalah lingkungan digital yang memungkinan transaksi komersial terjadi di antara banyak organisasi dan individu (Laudon dan Laudon, 2008). Electornic commerce adalah pembelian, penjualan, dan pemasaran barang serta jasa melalui sistem elektronik (Wong, 2010). E-Commerce meliputi transfer dana secara elektronik, pertukaran dan pengumpulan data. Semua di atur dalam sistem manajemen inventori otomatis. Dalam konteks ecommerce B2C, fitur website online retailers dapat dikategorikan ke dalam tiga tahap pemasaran: presales, penjualan online, dan purna jual (Lin, 2007). Tahap presales mencakup upaya pengecer online untuk menarik pelanggan dengan menyediakan produk dan informasi terkait harga untuk mengurangi biaya pencarian pelanggan. Aktivitas pembelian elektronik pelanggan terjadi selama tahap penjualan online, di mana pesanan dilakukan dan pembayaran dilakukan secara elektronik. Tahap purna jual terdiri dari layanan pelanggan, pengiriman, dan solusi masalah. Tahapan ini harus menghasilkan atau menumbuhkan kepuasan pelanggan jika berbagai kebutuhan dan harapan pelanggan terpenuhi. Dengan demikian, kepuasan pelanggan dapat dicapai secara efektif melalui kegunaan website dan dengan kualitas layanan pelanggan selama ketiga tahap pemasaran.

Dalam lingkungan e-commerce virtual, website adalah pertama dan alat penghubung utama bagi interaksi dengan konsumen potensial. Website telah menjadi satu-satunya sarana untuk menyampaikan informasi, berkomunikasi dengan calon konsumen dan meningkatkan kesadaran produk (Ness, 2006) dalam (Cho, Bonn dan Kang, 2014). Sistem website yang interface dengan konsumen dapat memainkan peran penting dalam mengurangi risiko yang dirasakan dengan belanja online (Brown et al., 2003), banyak perusahaan-perusahaan AS secara online telah membuat upaya untuk mengembangkan website yang efektif yang dapat membangun hubungan yang positif dengan konsumen serta lebih meningkatkan pendapatan penjualan secara online (Nowak dan Newton, 2008) dalam (Cho, Bonn dan Kang, 2014). 


\section{User-Generated Content (UGC)}

Konten yang dibuat pengguna (Usergenerated content) atau media yang dibuat oleh konsumen menggambarkan apa pun yang dibuat oleh pengguna website (Cleary dan Bloom, 2011) dalam (Haigh dan Wigley, 2015). Christodoulides et al. (2012) dalam (Haigh dan Wigley, 2015) mendefinisikan konten yang dibuat pengguna (Usergenerated content) sebagai —-konsumen yang menciptakan konten yang disediakan melalui media transmisi yang dapat diakses publik seperti internet; mencerminkan beberapa tingkat upaya kreatif; dan dibuat secara gratis di luar rutinitas dan praktik profesionall. Ini termasuk blog, entri Wikipedia, video dan foto yang diposting, dan posting mikroblog di platform seperti Facebook dan Twitter.

Konten buatan pengguna (User - generated content/UGC) atau juga dikenal sebagai kata elektronik dari mulut ke mulut (eWOM) bekerja persis seperti kata-dari-mulut yang umum (Manap \& Adzharudin, 2013) dalam (Bahtar dan Muda, 2016) kecuali itu menyebar input melalui media online. Menurut definisi, UGC mengacu pada materi yang dibuat sendiri yang diunggah ke Internet oleh nonmedia dan memiliki pengaruh yang lebih besar pada konsumsi masyarakat (Cheong \& Morrison, 2008; Dijck, 2009; Jonas, 2010; Krishnamurthy \& Dou, 2010; Presi, Saridakis, \& Hartmans, 2014) dalam (Bahtar dan Muda, 2016) di mana isinya umumnya dibagikan di media sosial seperti di facebook, YouTube, Twitter dan Instagram.

Hennig-Thurau, Gwinner, Walsh, \& Gremler (2004) dalam (Bahtar dan Muda, 2016) mendefinisikan eWOM/UGC sebagai berikut -..setiap pernyataan positif atau negatif dibuat oleh pelanggan potensial, aktual, atau pelanggan yang pernah merasakan produk atau perusahaan tersebut yang kemudian disebarkan melalui media internet yang ditujukan untuk orang banyak.

UGC adalah konten yang diterbitkan di website yang dapat diakses publik atau di situs jejaring sosial yang perlu menunjukkan sejumlah upaya kreatif, dan telah dibuat di luar rutinitas dan praktik profesional (Kaplan dan Haenlein, 2010) dalam (Estrella-Ramón dan Ellis-Chadwick, 2017). Ini dapat dikembangkan oleh individu atau secara kolaboratif, serta diproduksi, dimodifikasi, dibagikan dan dikonsumsi. Ini pada dasarnya mewakili jumlah semua cara di mana orang memanfaatkan komunikasi dengan merek secara online dan media lain seperti jaringan sosial (Kaplan dan Haenlein, 2010) dalam (EstrellaRamón dan Ellis-Chadwick, 2017). UGC terkait (misal Lebih luas dari) tetapi tidak identik dengan elektronik dari mulut ke mulut (e-WOM). e-WOM dapat didefinisikan sebagai pernyataan positif atau negatif yang dibuat oleh pelanggan potensial, aktual atau sebelumnya tentang suatu produk atau perusahaan yang tersedia untuk banyak orang dan lembaga melalui internet (Hennig-Thurau et al., 2004) dalam (Estrella-Ramón dan Ellis-Chadwick, 2017).

UGC dan e-WOM serupa ketika mereka ditemukan di online brand communication (OBC) dan terkait dengan merek itu sendiri atau produk yang ditawarkannya (Smith et al., 2012) dalam (EstrellaRamón dan Ellis-Chadwick, 2017).

Penelitian sebelumnya memperoleh hasil beragam mengenai pengaruh valensi ulasan pengguna (yaitu apakah komentar positif atau negatif) terhadap penjualan (Floyd et al., 2014; You et al., 2015) dan hasil psikologis lainnya (Purnawirawan et al., 2015) dalam (Estrella-Ramón dan Ellis-Chadwick, 2017). Terlepas dari kenyataan ini, beberapa penulis 
menggarisbawahi pentingnya ulasan pelanggan online dengan menunjukkan bahwa informasi positif / negatif yang ditemui online dapat menjadi faktor pemicu untuk memodifikasi perilaku pelanggan (yaitu membeli / tidak membeli) (Adjei et al., 2010; Chevalier dan Mayzlin, 2006; Veloutsou et al., 2017) dalam (Estrella-Ramón dan Ellis-

Chadwick, 2017). Secara khusus, e-WOM positif (dalam bentuk pesan teks) mencakup pengalaman dan rekomendasi yang menguntungkan untuk membeli produk tertentu, sementara e-WOM negatif mengacu pada pengalaman dan rekomendasi yang tidak menguntungkan untuk tidak membeli produk tertentu, dimotivasi terutama oleh keinginan untuk mengatasi suatu ketidakadilan yang dirasakan (Luo, 2009) dalam (Estrella-Ramón dan Ellis-Chadwick, 2017). Seperti yang telah dicatat sebelumnya, UGC lebih luas dari eWOM, tetapi keduanya tumpang tindih ketika UGC ditemukan dalam online brand communication (OBC )dan terkait dengan merek atau produk yang ditawarkannya (Smith et al., 2012) dalam (EstrellaRamón dan Ellis-Chadwick, 2017). Oleh karena itu, peneliti dapat menyatakan bahwa e-WOM positif (yaitu komentar positif

Penelitian menunjukkan bahwa konsumen yang terlibat dengan UGC (user-generated content) cenderung membela merek, berbagi pendapat tentang merek dan produk dengan konsumen lain (Schivinski dan Dabrowski, 2016). UGC (user-generated content) juga dianggap oleh konsumen sebagai dapat dipercaya, yang membuat jenis komunikasi ini lebih berpengaruh daripada iklan tradisional (Christodoulides, 2012) dalam (Schivinski dan Dabrowski, 2016).

\section{Kredibilitas Informasi}

Kredibilitas sumber adalah sejauh mana target pemirsa memandang sumbernya itu memiliki keahlian (expertise) dan pengetahuan (knowledge) dalam pemahaman mereka tentang produk / layanan (Ohanian, 1990; Teng, Wei Khong, Wei Goh, \& Yee Loong Chong, 2014) dalam (Djafarova dan Rushworth, 2017). Secara konvensional kredibilitas sumber mempertimbangkan karakteristik dari narasumber didalam mempersuasif (biasanya terjadi pada tradisional), adapun karakteristik kredibilitas narasumber mencakup keahlian dan kepercayaan, kedinamisan, ketenangan, kemampuan bersosialisasi, kesukaan pada sumber, dan kemiripan dengan sumber.

Kredibilitas pesan adalah bagaimana karakteristik pesan atau informasi dapat membentuk kepercayaan audiens (Flanagin dan Metzger, 2008). Dimensi utama kredibilitas pesan meliputi struktur pesan, konten, bahasa, dan pengiriman. Aspek konten pesan seperti akurasi, penggunaan produk yang merupakan sebagai bukti dan komentar, kelengkapan, dan mata uang telah terbukti mempengaruhi persepsi kredibilitas informasi online. Selain itu, Fogg et al. menemukan bahwa karakteristik struktural dari pesan online, seperti organisasi mereka (atau kemampuan navigasi), dan elemen pengiriman pesan, seperti adanya kesalahan tipografi, mempengaruhi penilaian kredibilitas.

\section{Gambar 4. Kerangka Pemikiran}

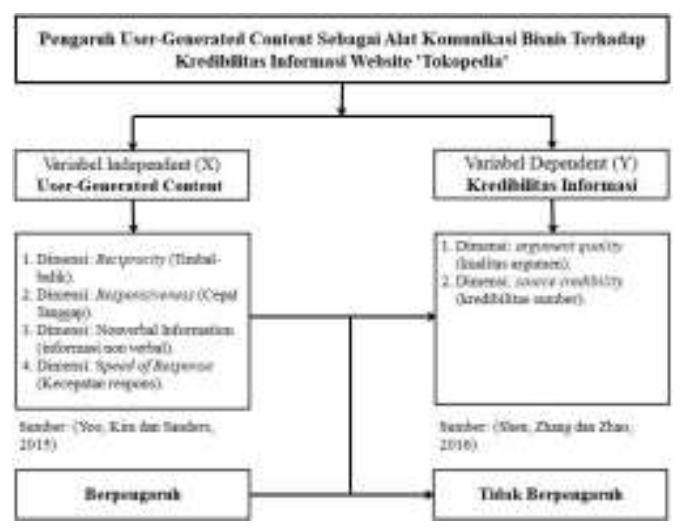




\section{METODE PENELITIAN}

\section{Paradigma Penelitian}

Pendekatan penelitian yang digunakan positivistik atau objektif. (West dan Turner, 2009) Pendekatan/paradigma positivistik (empiris) adalah pendekatan yang berasumsi akan adanya realita yang objektif. Dari definisi pendekatan positivistik, dapat penulis analisis yakni setiap penelitian yang menggunakan pendekatan positivistik artinya penelitian tersebut harus sesuai dengan realitas faktanya di lapangan sehingga penelitian baru dapat dikatakan objektif, yang secara tegas menyatakan dirinya adalah — Positifl yang berarti — nyatall. Hasil penelitian dikatakan nyata dan objektif dikarenakan telah mengikuti kaidah-kaidah penelitian yakni penelitian yang dibuat harus sesuai dengan kaidah pengetahuan, dalam arti kata bahwa penelitian yang dibahas harus didukung oleh teori yang tepat dan konsep dari teori tersebut telah memiliki alat ukur atau operasionalisasi konsep yang jelas. Selanjutnya, kaidah penelitian harus mengikuti alur pemikiran deduktif (yakni membuat hipotesis terlebih dulu kemudian dibuktikan di lapangan melalui penyebaran kuesioner), hasil penyebaran kuesioner tersebut diuji secara statistik sehingga hasil angka-angka tersebut dikatakan objektif dan real (nyata) apa adanya.

\section{Pendekatan Penelitian}

Penelitian ini menggunakan pendekatan
kuantitatif. Penelitian kuantitatif menjelaskan
fenomena dengan mengumpulkan data yang berupa
angka-angka, lalu data dianalisis dengan menggunakan

metode berbasis matematik (khususnya data berupa angka-angka) (Muijs, 2011).

Pendekatan kuantitatif biasanya dikaitkan dengan perspektif positivistik dalam penelitian sosial. Hammersley (1993a) =metode kuantitatif* mengacu pada sebagian besar untuk penerapan percobaan ilmu alam sebagai model untuk penelitian ilmiah, dimana pendekatan positivistik itu merupakan atribut utama untuk pengukuran kuantitatif dari fenomena yang diteliti dan secara sistematik untuk mengkontrol teori variabel yang mempengaruhi fenomena tersebut (Henn, Weinstein dan Foard, 2006).

\section{Jenis Penelitian}

Jenis penelitian yang digunakan eksplanatif. (Kriyantono, 2008) Penelitian eksplanatif adalah jenis penelitian yang menjelaskan hubungan antara dua atau lebih variabel.

Variabel penelitian yang dihubungkan terdiri dari variabel bebas (X): User - Generated Content sebagai alat komunikasi bisnis dan variabel terikat (Y): Kredibilitas Informasi Website.

\section{Teknik Pengumpulan Data}

Populasi dalam penelitian terdiri atas semua orang yang termasuk dalam kategori tertentu (West dan Turner, 2009). Populasi merupakan sekelompok individu, benda, atau item-item yang berasal dari manapun, yang mana hal itu akan dijadikan sampel sebagai alat untuk pengukuran (K. Singh, 2007). Sampel adalah sekelompok orang yang dipilih untuk mewakili suatu populasi (West dan Turner, 2009). Jumlah populasi penelitian lebih dari 10.000 orang. 
Teknik pengambilan sampel yang digunakan purposive sampling. Alasan menggunakan purposive sampling yakni peneliti ingin mendapatkan informasi yang akurat dari konsumen yang telah menggunakan website Tokopedia untuk transaksi belanja online karena konsumen telah merasakan langsung berbelanja melalui media website.

Teknik pengambilan sampel yang digunakan dalam penelitian ini purposive sampling yang termasuk kategori non probability sampling. Sampling purposive, sesuai namanya, dilakukan dengan tujuan, yang berarti pemilihan unit sampling bersifat purposive (K. Singh, 2007).

Kriteria yang digunakan teknik sampling purposive yakni konsumen generasi $\mathrm{Y}$, dengan alasan sebagai berikut: Rentang usia konsumen Generasi Y cukup luas, dan mungkin ada beberapa perbedaan di antara mereka. Populasi yang diminati dalam penelitian ini adalah sub kelompok konsumen Generasi Y tertentu. Pegawai yang bekerja di Gedung Mayapada Tower 2 (Jalan Jend. Sudirman kav 28 Jakarta Selatan) yang pernah melakukan transaksi di website Tokopedia dipilih sebagai target responden karena alasan mereka adalah generasi yang dibesarkan di era teknologi (Roach, 2009) dalam (Tan dan Leby Lau, 2016).

Kemudian, sebelum peneliti memberikan kuesioner kepada pegawai yang bekerja Gedung Mayapada Tower 2 tentunya menanyakan terlebih dulu seperti apakah pernah melakukan pembelian produk secara online melalui website Tokopedia. Apabila pegawai pernah transaksi pembelian belanja online di website Tokopedia maka peneliti memberikan kuesioner. Hal ini peneliti lakukan, untuk memastikan bahwa pegawai tersebut telah memiliki pengalaman berbelanja online melalui website
Tokopedia sehingga pegawai dapat menjawab pernyataan kuesioner yang terkait dengan kontenkonten di website Tokopedia.

Tabel 1. Operasinalisasi Variabel

\begin{tabular}{|c|c|c|c|}
\hline Variabel & Dimensi & Indikator & $\begin{array}{l}\text { Skala Pengukuran } \\
\text { Likert }\end{array}$ \\
\hline \multirow[t]{4}{*}{$\begin{array}{l}\text { User } \\
\text { Generated } \\
\text { Content } \\
\text { (Variabel } \\
\text { X) }\end{array}$} & $\begin{array}{l}\text { Recipcrocit } \\
\text { y (Timbal- } \\
\text { Balik) }\end{array}$ & $\begin{array}{l}\text { 1. Mudah Mengirim } \\
\text { Komentar } \\
\text { 2. Mudah Melihat } \\
\text { Komentar } \\
\text { 3. Komentar Negatif }\end{array}$ & $\begin{array}{lr}\text { Sangat } & \text { Tidak } \\
\text { Setuju=1, } & \text { Tidak } \\
\text { Setuju = 2, Ragu- } \\
\text { ragu = 3, Setuju = 4, } \\
\text { Sangat Setuju }=5\end{array}$ \\
\hline & $\begin{array}{l}\text { Responsive } \\
\text { ness }\end{array}$ & $\begin{array}{l}\text { 1. Ulasan pelanggan } \\
\text { 2. Ulasan pelanggan } \\
\text { dibutuhkan } \\
\text { 3. Ulasan pelanggan } \\
\text { relevan } \\
\text { 4. Ulasan Pelanggan } \\
\text { bermanfaat }\end{array}$ & \\
\hline & \begin{tabular}{|l|} 
Nonverbal \\
Information \\
(Informasi \\
non verbal)
\end{tabular} & $\begin{array}{l}\text { 1. Ulasan } \\
\text { menggunakan teks } \\
\text { atau kalimat } \\
\text { 2. Posting komentar } \\
\text { 3. Website } \\
\text { memberikan } \\
\text { keuntungan ekstra }\end{array}$ & \\
\hline & $\begin{array}{l}\text { Speed of } \\
\text { Response } \\
\text { (Kecepatan } \\
\text { Respons }\end{array}$ & $\begin{array}{l}\text { 1. Pertanyaan } \\
\text { pelanggan dijawab } \\
\text { cepat } \\
\text { 2. Penjual merespon } \\
\text { keluhan konsumen } \\
\text { 3. Konsumen cepat } \\
\text { mendapatkan } \\
\text { jawaban }\end{array}$ & \\
\hline
\end{tabular}




\begin{tabular}{|c|c|c|c|}
\hline Variabel & Dimensi & Indikator & $\begin{array}{c}\text { Skala } \\
\text { Pengukuran } \\
\text { Likert }\end{array}$ \\
\hline $\begin{array}{l}\text { Kredibilitas } \\
\text { Informasi }\end{array}$ & $\begin{array}{l}\text { Argument } \\
\text { Quality } \\
\text { (Kualitas } \\
\text { Argumen }\end{array}$ & $\begin{array}{l}\text { 1. Ulasan Konsumen lengkap } \\
\text { 2. Ulasan konsumen akurat } \\
\text { 3. Ulasan konsumen objektif }\end{array}$ & $\begin{array}{lr}\text { Sangat } & \text { Tidak } \\
\text { Setuju=1, } & \text { Tidak } \\
\text { Setuju = 2, Ragu- } & \text { ragu = 3, Setuju = } \\
\text { 4, Sangat Setuju = } \\
5\end{array}$ \\
\hline & $\begin{array}{l}\text { Source } \\
\text { Credbility } \\
\text { (Kredibilita } \\
\text { s Sumber) }\end{array}$ & $\begin{array}{ll}\text { 1. } & \text { Pengetahuan konsumen } \\
\text { mendalam } \\
\text { 2. Konsumen seorang pakar } \\
\text { 3. Komentar }\end{array}$ & \\
\hline
\end{tabular}

bisnis diperoleh nilai Kaiser-Meyer-Olkin Measure of

\section{PEMBAHASAN}

Tabel 2. Hasil Uji Validitas dan Reliabilitas

Variabel Bebas (X)

\begin{tabular}{|c|c|c|c|c|c|}
\hline \multirow{2}{*}{ Variabel } & \multicolumn{4}{|c|}{$\begin{array}{r}\text { UJI } \\
\text { VALIDITAS }\end{array}$} & \multirow{2}{*}{$\begin{array}{c}\text { UJI } \\
\text { RELIABILI } \\
\text { TAS } \\
\begin{array}{c}\text { Hasil } \\
\text { Cronbach's } \\
\text { Alpha }\end{array}\end{array}$} \\
\hline & $\begin{array}{r}\mathrm{KM} \\
\mathrm{O}\end{array}$ & $\begin{array}{c}\text { Bartlett } \\
\text { s } \\
\text { Test }\end{array}$ & $\begin{array}{r}\text { Indika } \\
\text { tor }\end{array}$ & $\begin{array}{c}\text { Anti- } \\
\text { image } \\
\text { Correlati } \\
\text { on }\end{array}$ & \\
\hline \multirow[t]{13}{*}{$\begin{array}{l}\text { User-Generated } \\
\text { Content }\end{array}$} & $\begin{array}{r}0,74 \\
4\end{array}$ & 269,524 & X1 & 0,789 & \multirow{13}{*}{0,894} \\
\hline & & $\begin{array}{l}\text { Sig. } \\
0,000\end{array}$ & $\mathrm{X} 2$ & 0,761 & \\
\hline & & & X3 & 0,805 & \\
\hline & & & $\mathrm{X} 4$ & 0,729 & \\
\hline & & & X5 & 0,756 & \\
\hline & & & X6 & 0,810 & \\
\hline & & & X7 & 0,749 & \\
\hline & & & $\mathrm{X} 8$ & 0,734 & \\
\hline & & & X9 & 0,696 & \\
\hline & & & $\mathrm{X} 10$ & 0,808 & \\
\hline & & & X11 & 0,759 & \\
\hline & & & X12 & 0,610 & \\
\hline & & & X13 & 0,670 & \\
\hline
\end{tabular}

Sampling Adequacy pada nilai $\mathrm{KMO} \geq 0,6$ maka hasil uji validitas ini memperlihatkan bahwa sampel yang digunakan dalam penelitian dapat dikatakan cukup memadai untuk mengevaluasi indikator yang menjadi faktor dari variabel penelitian. Dengan perkataan lain, indikator dalam penelitian ini merepresentasikan variabel penelitian dan layak untuk dianalisis.

Berdasarkan hasil data penelitian pada uji validitas User - Generated Content sebagai alat komunikasi bisnis menunjukkan bahwa ternyata indikator dari variabel User - Generated Content menunjukkan hasil data yang valid karena nilai antiimage correlationsnya berada di atas (>) 0,5.

Hasil uji reliability statistics pada dimensi User - Generated Content sebagai alat komunikasi bisnis diperoleh angka Cronbach's Alpha yang lebih besar dari batas minimum Alpha Cronbach sebesar 0,6. Artinya bahwa dimensi pada variabel bebas User - Generated Content sebagai alat komunikasi bisnis ini dapat dikatakan reliability atau konsisten. 
Tabel 3. Hasil Uji Validitas dan Reliabilitas Variabel Terikat (Y)
Tabel 4. Model Summary

\begin{tabular}{|c|c|c|c|c|c|}
\hline \multirow{2}{*}{ Variabel } & \multicolumn{4}{|c|}{$\begin{array}{l}\text { UJI } \\
\text { VALID } \\
\text { ITAS }\end{array}$} & \multirow{2}{*}{\begin{tabular}{|c} 
UJI \\
RELIABILITAS \\
Hasil \\
Cronbach`s \\
Alpha
\end{tabular}} \\
\hline & $\begin{array}{r}\mathrm{KM} \\
\mathrm{O}\end{array}$ & $\begin{array}{c}\text { Bartlett's } \\
\text { Test }\end{array}$ & $\begin{array}{c}\text { Indikato } \\
\mathrm{r}\end{array}$ & $\begin{array}{c}\text { Anti- } \\
\text { image } \\
\text { Correlatio } \\
n\end{array}$ & \\
\hline \multirow[t]{7}{*}{$\begin{array}{l}\text { Kredibilitas } \\
\text { Informasi }\end{array}$} & $\begin{array}{r}0,73 \\
3\end{array}$ & 116,051 & Y1 & 0,670 & \multirow{7}{*}{0,849} \\
\hline & & Sig. 0,000 & $\mathrm{Y} 2$ & 0,656 & \\
\hline & & & Y3 & 0,916 & \\
\hline & & & Y4 & 0,766 & \\
\hline & & & Y5 & 0,753 & \\
\hline & & & Y6 & 0,731 & \\
\hline & & & Y7 & 0,814 & \\
\hline
\end{tabular}

\begin{tabular}{|c|c|c|c|c|}
\hline Model & $\mathrm{R}$ & $\begin{array}{c}\mathrm{R} \\
\text { Squa } \\
\mathrm{r}\end{array}$ & $\begin{array}{l}\text { Adjusted } \\
\text { R Square }\end{array}$ & $\begin{array}{c}\text { Std. Error of } \\
\text { the Estimate }\end{array}$ \\
\hline 1 & $.624^{\mathrm{a}}$ & .389 & .382 & 4.441 \\
\hline
\end{tabular}

a. Predictors: (Constant), User - Generated Content sebagai alat komunikasi bisnis

b. Dependent Variable: Kredibilitas Informasi Website Tokopedia

Besarnya hasil koefisien korelasi user generated content dengan kredibilitas informasi website Tokopedia, diperoleh hasil R hitung sebesar 0,624 yang berdasarkan pedoman interval korelasi termasuk kategori hubungan kuat, karena berada

Mengacu hasil analisis faktor pada variabel bebas Kredibilitas Informasi diperoleh nilai KaiserMeyer-Olkin Measure of Sampling Adequacy pada nilai $\mathrm{KMO} \geq 0,6$ maka hasil uji validitas ini memperlihatkan bahwa sampel yang digunakan dalam penelitian dapat dikatakan cukup memadai untuk mengevaluasi indikator yang menjadi faktor dari variabel penelitian. Dengan perkataan lain, indikator dalam penelitian ini merepresentasikan variabel penelitian dan layak untuk dianalisis.

Berdasarkan hasil data penelitian pada uji validitas Kredibilitas Informasi menunjukkan bahwa ternyata indikator dari variabel Kredibilitas Informasi menunjukkan hasil data yang valid karena nilai antiimage correlationsnya berada di atas (>) 0,5.

Hasil uji reliability statistics pada dimensi Kredibilitas Informasi diperoleh angka Cronbach's Alpha yang lebih besar dari batas minimum Alpha Cronbach sebesar 0,6. Artinya bahwa dimensi pada variabel terikat Kredibilitas Informasi ini dapat dikatakan reliability atau konsisten. pada rentang interval antara 0,60 - 0,799 seperti yang direkomendasikan (Sugiyono, 2012).

Berdasarkan temuan data penelitian pada tabel di atas, dapat diketahui dengan jelas perolehan besarnya persentase kredibilitas informasi website Tokopedia setelah dipengaruhi user - generated content, dari kolom R square adalah 0,389 setelah dikonversi ke dalam bentuk persentase maka 0,38,9 x 100\% $=38,9 \%$ dan sisanya $100 \%-38,9 \%=61,1 \%$ yang berasal dari faktor-faktor lain yang tidak peneliti teliti seperti faktor kualitas produk, harga produk, citra merek, dan promosi.

\section{KESIMPULAN}

Berdasarkan hasil uji (t signifikansi) menunjukkan bahwa bahwa user - generated content sebagai alat komunikasi bisnis secara berpengaruh signifikan terhadap kredibilitas informasi website Tokopedia. Artinya bahwa konten atau komentar yang dibuat pengguna lain di website Tokopedia ini terlihat 
kredibel sehingga konsumen lain yang membacanya percaya dengan informasi yang tertera di kolom komentar.

Besar Pengaruh User - Generated Content sebagai Alat Komunikasi Bisnis Terhadap Kredibilitas Informasi Website Tokopedia, diperoleh sebesar 0,624 termasuk kategori hubungan kuat. Artinya bahwa konten atau ulasan produk yang dibuat pengguna lain di Website Tokopedia terlihat informasinya kredibel, hal ini dibuktikan dari perolehan nilai mean yang tinggi pada indikator banyak komentar ulasan (review comments) yang diposting di website Tokopedia ini menggunakan teks/kalimat, kemudian konsumen dapat dengan mudah membuat komentar atau konten di website Tokopedia serta mudah dilihat pula kontenkonten tersebut oleh pihak lain. Selanjutnya, yang membuat konten tersebut terlihat kredibel dikarenakan pengguna menyampaikan ulasan produknya menggunakan bahasa berupa kalimat dan teks. Bentuk ulasan produk yang dibuat pengguna lain ini dinilai akurat dan objektif terkait produk sehingga kontenkontennya dapat diandalkan oleh konsumen sebelum memutuskan tindakan pembelian.

\section{DAFTAR PUSTAKA}

\section{Sumber Buku}

Babbie, E., William E. Wagner, I., dan Zaino, J. (2015). Adventures in Social Research : Data Analysis Using IBM® SPSS® Statistics (9 ed.). United Kingdom: SAGE Publications, Inc.

Bisen, V., dan Priya. (2009). Business Communication. New Delhi: New Age International (P) Limited.

Bovée, C. L., dan Thill, J. V. (2014). Business Communication Essentials (6 ed.).
Connolly, P. (2007). Quantitative Data Analysis in Education A Critical Introduction Using SPSS. USA and Canada: Routledge.

Das, K., Tamhane, T., Vatterott, B., Wibowo, P., dan Wintels, S. (Agustus 2018). The digital archipelago: How online commerce is driving Indonesia's economic development. Retrieved from Indonesia:

Durand, M. A., dan Chantler, T. (2014). Principles of Social Research (2 ed.). England: Open University Press, McGraw- Hill Education.

Elliott, A. C., dan Woodward, W. A. (2007). Statistical Analysis Quick Reference Guidebook: With SPSS Examples. Thousand Oaks, California: Sage Publications, Inc.

Field, A. (2009). Discovering statistics using SPSS (and sex and drugs and rock ' $n$ ' roll) (3 ed.). London: Sage Publications, Ltd.

Fitrah, M., dan Luthfiyah. (2018). Metodologi Penelitian: Penelitian Kualitatif,

Tindakan Kelas \& Studi Kasus. Jawa Barat: Jejak Publiser.

Henn, M., Weinstein, M., dan Foard, N. (2006). A Short Introduction to Social Research (1 ed.). London: SAGE Publications.

Hermawan, A. (2017). Penelitian Bisnis Paradigma Kuantitatif. Jakarta: CV Grasindo.

Kriyantono, R. (2008). Teknik Praktis Riset Komunikasi. Jakarta: CV Kencana.

Sungkono \& M. E. P., Trans.). In N. Setyaningsih (Ed.), Buku 2 (10 ed.). Jakarta: Salemba Empat.

Miller, G. J., dan Yang, K. (Eds.). (2008). Handbook of research methods in public administration (2 ed.). United States of America: Auerbach Publications (Taylor \& Francis Group).

Muijs, D. (2011). Doing Quantitative Research in Education with SPSS (2 ed.). London: SAGE Publications Ltd.

Peat, J., dan Barton, B. (2014). Medical Statistics : A Guide to SPSS, Data Analysis and Critical Appraisal. West Sussex, UK: John Wiley \& Sons, Incorporated.

Pickton, D., dan Broderick, A. (2005). Integrated marketing communications (2 ed.). England: Pearson Education Limited. 
Purwanto, D. (2006). Komunikasi Bisnis (3 ed.). Jakarta: Erlangga.

Singh, K. (2007). Quantitative Social Research Methods. New Delhi: Sage Publications India Pvt Ltd.

Solomon, M. R., Marshall, G. W., dan Stuart, E. W. (2012). Marketing : real people, real choices (7 ed.). United States of America: Pearson Education, Inc.

Sugiyono. (2012). Metode Penelitian Administrasi. Bandung: CV Alfabeta.

Sugiyono. (2013). Metode Penelitian Bisnis. Alfabeta. Bandung. Bandung: CV. Alfabeta.

Tench, R., dan Yeomans, L. (2009). Exploring Public Relations (2 ed.). England: Pearson Education Limited.

Varey, R. J. (2002). Marketing Communication: A Critical Introduction (1 ed.). USA and Canada: Routledge.

Weiers, R. M. (2011). Introduction to Business Statistics (7 ed.). USA: South-Western, Cengage Learning.

West, R., dan Turner, L. H. (2009). Pengantar Teori Komunikasi Analisis dan Aplikasi (Buku 1) (N. Setyaningsih, Trans. 3 ed.). Jakarta: Salemba Humanika.

Wong, J. (2010). Internet Marketing For Beginners. Jakarta: PT Elex Media Komputindo.

Zikmund, W. G., dan Babin, B. J. (2007). Exploring Marketing Research (9 ed.). United States of America: Thomson Higher Education/Cengage Learning.

Zikmund W.G., dan Babin, B.J.. (2009).Business Research Methods (with Qualtrics Card) (8 ed.). South-Western: Cengage Learning.

\section{Sumber Jurnal}

Bahtar, A. Z., dan Muda, M. (2016). The Impact of User - Generated Content (UGC) on Product Reviews towards Online Purchasing - A Conceptual Framework. Procedia Economics and Finance, 37, 337-342.

Cho, M., Bonn, M. A., dan Kang, S. (2014). Wine attributes, perceived risk and online wine repurchase intention: The cross-level interaction effects of website quality. International Journal of Hospitality Management, 43, 108-120.

Costa e Silva, S., dan Elo, M. (2018). Chapter 9 New Digital Layers of Business Relationships Experiences from Business-to-business Social Media. 13, 217-241.

Djafarova, E., dan Rushworth, C. (2017). Exploring the credibility of online celebrities' Instagram profiles in influencing the purchase decisions of young female users. Computers in Human Behavior, 68, 1-7.

Dolan, R., Conduit, J., Fahy, J., dan Goodman, S. (2017). Social media: communication strategies, engagement and future research directions. International Journal of Wine Business Research, 29(1), 2-19.

Estrella-Ramón, A., dan Ellis-Chadwick, F. (2017). Do different kinds of user-generated content in online brand communities really work? Online Information Review, 41(7), 954968.

Flanagin, A. J., dan Metzger, M. J. (2008). Digital Media and Youth: Unparalleled Opportunity and Unprecedented Responsibility. 5-28.

Floyd, K., Freling, R., Alhoqail, S., Cho, H. Y., dan Freling, T. (2014). How Online Product Reviews Affect Retail Sales: A Metaanalysis. Journal of Retailing, 90(2), 217232.

Haigh, M. M., dan Wigley, S. (2015). Examining the impact of negative, user-generated content on stakeholders. Corporate Communications: An International Journal, 20(1), 63-75.

Khajuria, I., dan Rachna. (2017). Impact of Social Media Brand Communications on Consumer-Based Brand Equity. Indian Journal of Commerce and Management Studies, 8(3), 124-131.

Lin, H.-F. (2007). The Impact of Website Quality Dimensions on Customer Satisfaction in the B2C E-commerce Context. Total Quality Management, 18(4), 363-378.

Mei Cao, Q. Z., dan Seydel, J. (2005). B2C ecommerce web site quality: an empirical examination. Industrial Management \& Data Systems, 105(5), 645-661. 
Mohtaramzadeh, M., Ramayah, T., dan Jun-Hwa, C. (2017). B2B E-Commerce Adoption in Iranian Manufacturing Companies: Analyzing the Moderating Role of Organizational Culture. International Journal of Human- Computer Interaction, 1-19.

Schivinski, B., dan Dabrowski, D. (2016). The effect of social media communication on consumer perceptions of brands. Journal of Marketing Communications, 22(2), 189-214.

\section{Website}

ASEAN. (2018). Top 10 e-commerce sites in Indonesia in 2018, by monthly traffic (in million clicks). Retrieved from https://wwwstatista-com

McKinsey. (2018). Number of online shoppers in Indonesia in 2017 and 2022 (in millions). Retrieved from https://www-statista-com

Richter, F. (2016). How Social Media Influences Shopping Behavior: The Great Influencer. Retrieved from https://www.statista.com/chart/6912/socialmedia-shopping-influence/ 